\title{
IRACIONALUMO APRAIŠKOS XX A. UŽSIENIO IR LIETUVOS ARCHITEKTÜROJE
}

\author{
Algimantas M. Mačiulis \\ Architektūros katedra, Vilniaus Gedimino technikos universitetas, \\ Pylimog. 26/Trakug. 1, 01332 Vilnius, Lietuva \\ El.paštas algimantasmaciulis@yahoo.com \\ Iteikta 20100617
}

Santrauka. Straipsnyje analizuojamas iracionalumas kaip šiuolaikinės architektūros meninės išraiškos forma, aptariama iracionalumo sąvoka architektūros mene. Taip pat charakterizuojamos sociokultūrinės prielaidos, filosofinès, meno srovès, dariusios įtaką iracionalumo požymiams architektūroje. Nagrinejjami pasauliniai ir Lietuvos iracionaliosios architektūros analogai, apžvelgiamos iracionalumo apraiškos stilistineje architektūros raidoje.

Reikšminiai žodžiai: iracionalumas, racionalumas, dekoratyvumas, plastiškumas, skulptūrinẻ forma, daugiasluoksniškumas, daugiaplaniškumas.

\section{Ivadas}

Iracionalumo sąvoka, vertinant estetinius architektūros bruožus, nèra plačiau vartojama, šiuo terminu dažniau pabrežiamas architektūros ekspresyvumas, meninis raiškos laisvumas. Architektūros tyrinètojas Ch. Jencks užsimena, jog iracionalumas būdingas vèlyvajam modernizmui, postmodernizmui ir dekonstruktyvizmui (Jencks 1982: 16). R. Buivydas iracionalizmo sąvoką vartoja nagrinèdamas jau XX a. pradžios filosofijos, meno, taip pat ir architektūros tendencijas, art deco, organinę architektūrą, taip pat iracionalumą ¡̇žvelgia simbolistineje architektūroje (Buivydas 1999). L. Nekrošius daktaro disertacijoje "Struktūralizmo idèjos šiuolaikinejje Lietuvos architektūroje" apžvelgia keletą iracionalių vèlyvojo Lietuvos modernizmo pavyzdžių (Nekrošius 2008). K. Lupeikis monografijoje "Minimalizmo galia“ tyrinejja hiperpaviršius, jų santykị su minimaliąja architektūra (Lupeikis 2007). Itvairaus pobūdžio deformacijas nagrinèja daugelis užsienio architektų (P. Schumacher, G. Lynn ir kt.). Straipsnio tikslas - apibrèžti iracionalumo sąvoką architektūroje, apžvelgti sociokultūrines iracionaliosios architektūros atsiradimo prielaidas. Straipsnyje išski- riami keli iracionalumo raiškos būdai, apžvelgiama šiuolaikinè Lietuvos ir pasaulinè iracionaliosios architektūros raida.

\section{Iracionalumas - samprata ir sąvokos}

Nagrinejjant iracionalumo apraiškas XX a. architektūroje, reikètų atkreipti demesị i tai, jog iracionali kryptis atsirasdavo kaip priešprieša racionaliai. Net ir pati sąvoka iracionalus kilusi kaip priešingybè lotyniškajai racionalus (lot. rationalis - protingas), reiškiančiai protingas, pagrịstas, apgalvotas, tikslingas, aiškiai suvokiamas, išreiškiamas. Lyg ir peršasi išvada, jog iracionalumas turètų būti kažkas neprotingo ar neapgalvoto, tačiau šiuolaikiniame moksle ir mene iracionalumas interpretuojamas kiek kitaip. „Moderniu požiūriu, iracionalizmo idejoje esminis vaidmuo priklauso ne tik priešpriešai racionalizmo absoliutaus proto fenomenui, bet ir ypatingos svarbos ir prasmès teikimui intuicijai, laisvai besireiškiančiam instinktui, jausmams, individualizmui. Kai kurioms iracionalizmo apraiškoms būdingas mistiškumas, arba 
priešingai - antitradiciškumas, spontaniškumas, neapibrèžtumas $<\ldots .$. . Charakteringas viso XX a. dvasinès būsenos ženklas esti nusivylimas tradicinèmis civilizacijos vertybėmis ir senųjų tiesų galiomis bei gyvybingumu. Dali visuomenès be perstojo kankina abejojimai idealios tvarkos pagrịstumu ir tikroviškumu, taip pat dèl proto viršenybès jausmams pripažinimo. Tam tikra intelektualioji visuomenès dalis, mąstydama apie visa tai ir suvokdama pasaulị kaip prieštarų, atsitiktinumų, neteisingumo ir chaotiškumo padarinị teigia sudètingumą, neapibrèžtumą ir visa ko leistinumą, kaip tam tikrą teisingą mūsų laiko reprezentaciją. Tokia samprata rado palankią terpę kai kuriose filosofinèse koncepcijose, meno, kartu ir architektūros tendencijose" - teigia R. Buivydas (1999: 71).

Racionalumas architektūrai būdingas nuo seniausių laikų. Taisyklingos formos pastatai, statūs kampai - vienas iš žmogaus sąmoningos veiklos bruožų, vienas pirmųjų architektūros pasiekimų, didelis žmogaus laimèjimas (Mačiulis 1997: 21). Pagrindiniai racionalios architektūros principai, Le Corbusier teigi$\mathrm{mu}$, - geometrinès formos grynumas, dominuojanti funkcijos svarba prieš formą. Racionalios architektūros pagrindiniai elementai - erdvé, kurią formuoja sienų plokštumos, taip pat šviesa ir šešèlis (Le Corbusier 1986: 2, 3, 5).

Nepaisant to, jog Le Corbusier plètojo racionaliosios architektūros kryptị, savo kūrybos pabaigoje jis Ronšano vietoveje, Prancūzijoje, suprojektavo ekspresyvią, iracionalios formos koplyčią (1 pav.), kuriai būdingos ir simbolizmo apraiškos. Visa tai išreikšta sunkia, iš dalies brutalia, tragiška, o iš dalies ir linksma geometrinių formų prieštaros jèga (Jencks 1982: 178). Ši koplyčia - plastiškiausias ir iracionaliausias pastatas, sukurtas modernizmo laikotarpiu (Stirling 1997: 16).

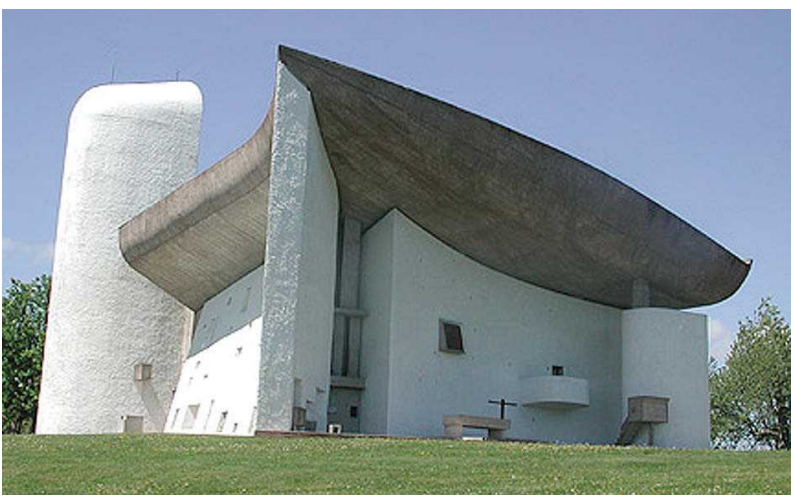

1 pav. Dievo Motinos koplyčia, archit. Le Corbusier. Ronšanas, Prancūzija. 1954 m.

Fig. 1. Chapel Notre Dame. Le Corbusier. Ronchamp, France. 1954.
Iracionalumo tendencijos, kaip jau buvo minèta, atsiranda kaip priešprieša racionalumui, pragmatiškumui, pozityvizmui, technicistinei morfologijai. Iracionalumas teigia kitokị meną, grindžiamas dekonstravimo, neapibrežtumo, grubumo, dramatiško ekspresyvumo, intuityvumo, atsitiktinumo nuostatomis, o meninei formai būdinga disharmonijos arba eklektikos bei atektoniškumo išraiška. Iracionalumas XX-ajame amžiuje skleidèsi tokiomis tendencijomis kaip kubizmas, futurizmas, suprematizmas, dada, siurealizmas, popartas, performansas, instaliacija. Architektūroje panaši ideologinè orientacija ir meninio vaizdo kitoniškumo ideja realizuota ekspresionizmo, organinès architektūros, brutalizmo, manierizmo, dekonstruktyvizmo, dearchitektūros tendencijomis. Galima tvirtinti, jog iracionali architektūra iš esmès reiškia priešpriešą istorinei harmonijos tradicijai, amžiaus pabaigoje šią disharmoniją imta suvokti kaip natūralų architektūros meniškumo kriterijų. „Pažymètina, jog visą šimtmetị kaip tik kova su šia tradicija savotiškai ịkvejpe ir teike potenciją kitokio meno iracionaliojo srauto puoselètojams“ - rašo R. Buivydas (2006b: 48).

Iracionalioje architektūroje efektui išgauti dažnai pasitelkiamos dekoravimo formos, tokiuose pastatuose konstrukcija yra paslepta, vyrauja dekoratyvumas, daugiasluoksniškumas, nors planinẻ struktūra lieka racionali (Mačiulis 1997: 116). Šiai dekoratyviajai tendencijai galima būtų priskirti tiek daugumos „naujojo stiliaus" architektūros (secession, jungenstil, modern, art nouveau, liberti) kūrinių, kuriuose vyrauja gausūs dekoro elementai, nors tūrio kompozicijoje ir dominuoja asimetrija (Buivydas 1999: 72), tiek art deco, vèlyvojo modernizmo bei postmodernistinio laikotarpio manieristų darbus. Kita vertus, iracionalumas architektūroje pasireiškia ne vien dekoratyvinèmis formomis ar skulptūriška morfologija. Organinès architektūros (žymiausi atstovai H. Haring, H. Scharoun ir kai kuriuose projektuose F. L. Wright), simbolizmo (kai kuriuose objektuose E. Saarinen, Le Corbusier, M. Botta ir kt.) bei dekonstruktyvizmo (Z. Hadid, P. Eisenmann, D. Libeskind, E. Moss, Coop Himmelb(l)au) srovių architektūroje matoma akivaizdi priešprieša harmonijai (Buivydas 1999: 76, 77).

\section{Iracionali forma}

„Architektūros vaizdo kūrime ypatingą vietą užima architektūros formos. Pastato kompozicijos idejja igyvendinama konstrukcinemis ir dekoratyvinemis formomis, kurios architektūroje išryškejja ịvairiai: viename pastate jos pastebimos tolygiai pasiskirstę, kituose 
vyrauja konstrukcijos arba plastinès formos; vienuose konstrukcijų ir architektūros formų gabaritai sutampa, kituose jie skirtingi“ - teigia A. Mačiulis (1997: 103). Taigi, nagrinèjant iracionalumą architektūroje, galima išskirti kelias jo apraiškas. Nulemtą dekoratyvumo ir konstruktyvumo.

Racionalumo ir iracionalumo priešpriešą tiek dailëje, tiek architektūroje iš dalies galima aptikti vèlyvosios gotikos laikotarpiu, vèliau, renesansą keičiant barokui. H. Wolfflin savo knygoje „Pamatinès meno istorijos sąvokos", noredamas perteikti renesanso ir baroko santykị, pasitelkia „aiškumo“ ir „neaiškumo“ terminus, teigdamas, jog tai yra dekoratyvumo, o ne imitavimo sąvokos. Šalia lengvai suvokiamo linijinio, formos grožio, esama ne visai suvokiamo paslaptingumo, nenuspejjamumo, kuris kiekvieną kartą atrodo kitoks. Tiek tapyboje, tiek skulptūroje statiškumą keitẻ dinamiškumas, atsirado neapibrèžtumo, tęstinumo pojūtis. Antikinei architektūrai būdingas formos grožis (gerokai vèliau, XX a. pradžioje tai išsamiau nagrinès Le Corbusier, tiesa, kalbėdamas apie funkcionalizmą), o barokui būdingas neaiškumas, $\mathrm{H}$. Wolfflin žodžiais tariant: „vaizdas visada turi kažką, kas išsprūsta iki galo nesuvokus“ (2000: 230). Negalima teigti, jog barokui pakeitus renesansą architektūra iš principo pasikeite, juk nebuvo atrasta jokių naujų konstrukcijų, nepasikeite ir planavimo principai. Pasak $\mathrm{H}$. Wolfflin, formos tiesiog neteko prasmès, jos naudotos „dèl gryno efekto “, iškraipomos dekoratyviniais elementais (2000: 231). Baroko meistrams svarbu buvo ne formos grynumas, ne mastelis ar tobulos proporcijos. Architektūra suvokta kaip supančios erdvès dalis, harmoningos visumos komponentas, kai nebūtina laikytis praeities taisyklių. Iš orderio ženklų jau kuriama ne griežta pro$\mathrm{za}, \mathrm{o}$ jaudinantis simbolių ir metaforų kupinas poezijos kūrinys - sonetas (Palaima 2006: 180).

Kaip baroko architektūra keitè renesanso architektūrą, panašiais principais „naujasis stilius“ pakeitè Europoje tuo metu vyravusị istoristini, eklektišką stilių. Svarbiausia to priežastimi reikètų laikyti Vakaru Europos šalių visuomenès sąmonèje nuo XIX a. antros pusès vyravusị kultūrinị nacionalizmą (Buivydas 1999: 71). „Naujasis stilius“ toleravo įvairias konstrukcines medžiagas, jų derinius, svarbiausia, kad pastatas būtų stilistiškai harmoningas. Architektūroje dominavo augaliniai motyvai, dekoracijos, ornamentika. Dekoratyvumas ir ekspresyvumas gausiai atsispindejo ir interjeruose, tačiau tradicinė, griežta planinè struktūra išliko (Gossel 1991: 46). Tam tikrų dekoratyvumo elementų galima ičvelgti ir tarpukaryje vyravusioje art deco tendencijoje. Šiam stiliui būdingas laisvumas, asimetriška plano kompozicija, aiškus stilistinès vienovès siekis (Buivydas 1999: 75).

Antroje XX-ojo amžiaus puseje, postmodernistiniu laikotarpiu, architektūroje vèlgi gausu eklektikos, ornamentikos, simbolių, orderio elementų. Arkos, kolonos, atliekančios vien dekoratyvinę funkciją, vyravo tiek interjeruose, tiek eksterjeruose. Dekoratyvi ornamentika, praeityje turejuusi daug simbolinès bei estetinès reikšmès ir nenaudota moderniojoje architektūroje, postmodernizmo mene buvo iš naujo prisiminta. Ornamentika naudojama vizualiai suskaldyti tūriui; „laužyti“ i ́ pastatą patenkančiai šviesai, taip siekiama sukurti šviesos ir šešèlių žaismą, nuobodžią sienos plokštumą suskaldyti vizualiais ritmais ir t. t. (Jencks 1982: 146).

Morfologijos iracionalumas XX-ajame amžiuje visų pirma pastebimas organinejje architektūroje. Šiai srovei būdingas ekspresyvumas, laisvumas, skulptūriškumas. Formos dažnai kuriamos panašiu principu, kaip skulptorius kuria skulptūrą, atkreipdamas demesi ị masių santykius, rakursus, šviesą ir šešèli, paviršiu faktūras (Mačiulis 1997: 116). Nors kurị laiką organinei architektūrai ir buvo būdinga dekoratyvi ornamenti$\mathrm{ka}$, tačiau trečiajame XX-ojo amžiaus dešimtmetyje, vyraujant funkcionalistinèms idejjoms, tradicinę ornamentiką pakeitè subtilios langų rèmų konstrukcijos, verandos, parapetai. Skulptūrinè forma šiuo laikotarpiu dažnai atskiriama nuo funkcionalios schemos naudojant balkonus, stogelius ir kitus architektūrinius elementus (Gossel 1991: 182,189).

Postmodernizmo laikotarpiu akcentuojamas interjero erdvès skaidymas, eksterjero daugiasluoksniškumas. Pasak Ch. Jencks: „Erdvès paslaptingos, sudètingos ir stebinančios". Priemonès tam pasiekti pasitelktos jvairios: pakreipta kompozicijos ašis, kurią naudojant sukuriamas neịprastas efektas - asimetriška simetrija; patalpų ir planinès struktūros daugiasluoksniškumas, prasilenkimas; nuožulnumas ir diagonalès; pozityvo ir negatyvo (vidaus ir išorès) reversas; ịvairios pusformès ir struktūriniai netiketumai (Jencks 1982: 200-217).

Skulptūrinių, iracionalių formų paieškos sustiprëjo šiuolaikinejje architektūroje. Atsiradus, o vèliau masiškai išplitus kompiuterinems technologijoms, formos transformacijos galimybès neregètai išsiplètè, visuotinè kompiuterizacija, naujų priemonių atsiradimas sudaro praktiškai neribotas naujų formų paieškos galimybes (Lupeikis 2007: 132). Architektūros tyrinètojai svarbiu faktoriumi kompiuterinių technologijų taikymui architektūroje laiko XX-ojo amžiaus 9 dešimtmečio 
architektūros krypti - dekonstruktyvizmą. Šis judèjimas lèmé, kad kompiuterinių technologijų taikymas atvèè dideles raiškos galimybes (Melvin 2007: 136). Šiuolaikinès architektūros tendencijos vadinamos ìvairiai - tiek morfogenetinèmis, tiek biomorfinèmis, tačiau 2008 m. 11-ojoje Venecijos architektūros bienaleje buvo pristatytas naujos, paremtos kompiuterinèmis technologijomis architektūros tendencijos - parametricizmo manifestas (Kučinskas 2009: 50). Iracionalios formos požiūriu, ši kryptis svarbi tuo, kad neigia iprastines formų tipologijas, platoniškos geometrijos objektus, pasikartojimus, tiesias linijas, tikslius kampus, skatina įvairaus pobūdžio formų deformacijas (Schumacher 2008).

\section{Iracionalumo apraiškos $\mathrm{XX}$ amžiaus užsienio architektūroje}

Stimulą keistis architektūrai XX-ajame amžiuje suteike tuo metu filosofijoje vyravusios idealizmo, reliatyvizmo, iracionalizmo, intuityvizmo, psichoanalizès, egzistencializmo, postmodernistinès hermeneutikos, dekonstruktyvizmo kryptys. Mene pastebimos kubizmo, simbolizmo, ekspresionizmo, dadaizmo, art deco, abstrakcionizmo, siurrealizmo, poparto, konceptualizmo ittakos. Didelę reikšmę turèjo ir aktyviausių architektų dalyvavimas bendruose ịvairių meno sričių sąjūdžiuose. Tai buvo ypač populiaru pirmojoje amžiaus pusèje (Buivydas 1999: 71).

Amžių sandūroje užgimusio "naujojo stiliaus“, daugelyje šalių vadinamo ịvairiai - modernu, liberti, jungendstil, art nouveau, epicentrų buvo daug, tačiau jų deklaruojamos vertybès, pamatiniai teiginiai, dažnai iš esmès skirdavosi. Vienintelis jų panašumas - siekis bet kokia kaina būti moderniam, šiuolaikiškam. Vien tam, kad būtų atskleistas šiuo dinamišku laikotarpiu vyravusios architektūros ịvairumas ir skirtingos iracionalumo apraiškos, būtina palyginti skirtingu šalių šio stiliaus atstovų - belgo Victor Horta, ispano Antonio Gaudi ir austro Otto Wagnerio - objektus. O. Wagnerio projektuoto „Majolikos namo“ planine struktūra pakankamai racionali, fasadas taip pat nepasižymi ekspresyvumu, tačiau vyraujanti polichromija ir ornamentai suteikia pastatui tam laikotarpiui būdingo dekoratyvumo (2 pav.). V. Horta suprojektuotas Tassel viešbutis Briuselyje - racionalaus plano, pagarbiai ịsiliejantis ị esamą užstatymą, netgi gana diskretiškas, nepaisant kiek gausiau dekoruoto eksterjero, tačiau dekoratyvumas pasireiške interjeruose (3 pav.). Viduje gausu ornamentikos, augalinių motyvų, metalo plastikos (Gossel 1991: 45, 62). A. Gaudi architektūros negalima vadinti vien dekoratyvia. Projektuodamas Casa Mila, architektas panaudojo metalo karkasą, taip išlaisvindamas funkciją, suteikdamas jai iracionalumo. Skulptūriškų formų fasadas tik atkartoja komplikuotą vidinę pastato struktūrą (4 pav.) (Mackay 1985: 29).

Antrajame XX a. dešimtmetyje praūžęs Pirmasis pasaulinis karas sustabde „naujojo stiliaus" natūralią raidą. Architektūroje pradejo vyrauti racionaliosios modernizmo tendencijos. Nepaisant to, ekspresyvi, organiška architektūra nebuvo iki galo nustumta ị šalị (Buivydas 1999: 72). Organinès architektūros atstovai H. Haring, E. Mendelsohn, F. L. Wright naudojo iracionalias, ekspresyvias ir skulptūriškas formas. E. Mendelsohn projektuotoje astrofizikos laborato-

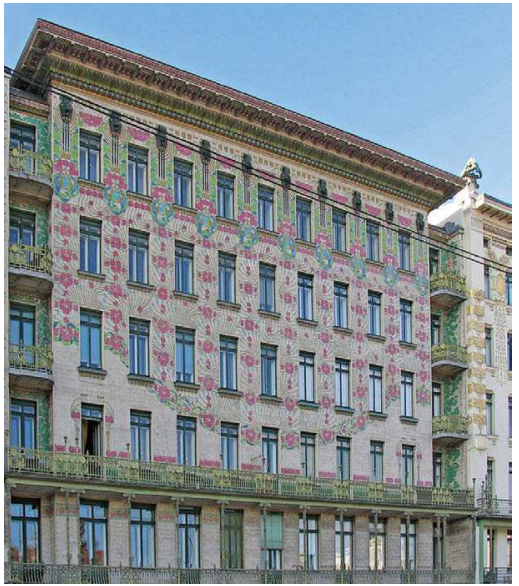

2 pav. „Majolikos namas“, archit. O. Wagner, Viena, Austrija. 1898-1899 m.

Fig. 2. "Majolika house". O. Wagner. Vienna, Austria. 1898-1899

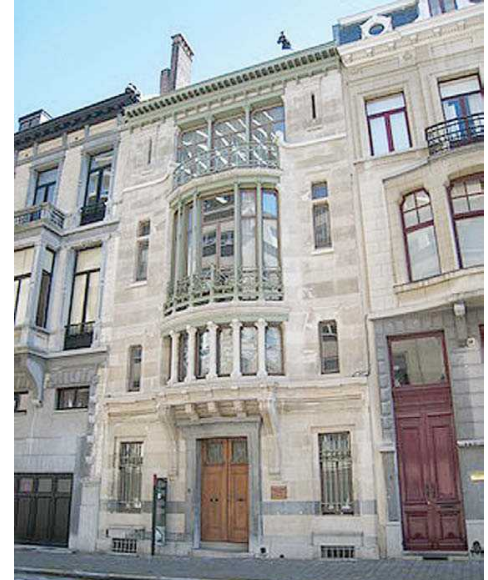

3 pav. Tassel viešbutis, archit. V. Horta, Briuselis, Belgija. 1893-1897 m.

Fig. 3. Hotel "Tassel". V. Horta. Brussels, Belgium. 1893-1897

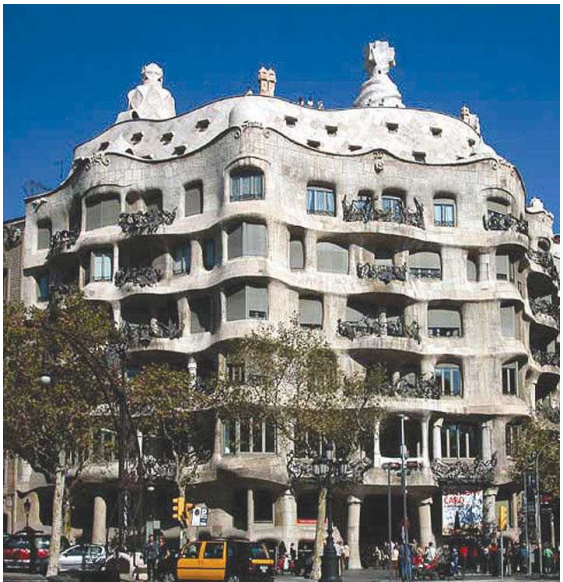

4 pav. Casa Mila, archit. A. Gaudi. Barselona, Ispanija. 1906-1910 m.

Fig. 4. "Casa Mila". A. Gaudi. Barcelona, Spain. 1906-1910 
rijoje ir observatorijoje Potsdame, nepaisant griežtai reglamentuotos, racionalios vidinès pastato struktūros, dekoratyvus išorès skulptūriškumas sukuria dinamiškos, laisvos architektoniškos formos ịspūdị (5 pav.) (Gossel 1991: 122). Dinamiškumas, judejimas buvo pagrindinè F. L. Wright suprojektuoto Guggenheimo muziejaus Niujorke ideja (6 pav.). Muziejuje lankytojas juda ratu, sraigtinès formos pandusu (Pfeiffer 2003: 151). İspūdingas, abstrahuotos architektūros pastatas primena kriauklę, jos gamtines, organines formas. Organinè architektūra turejo pasekejjų, ypač praeitame šimtmetyje.

Architektūros tyrinètojas $\mathrm{Ch}$. Jencks iracionalumą, statinių skulptūrines formas, simbolių panaudojimą vertina kaip velyvojo modernizmo ir postmodernizmo laikotarpiams būdingą architektūros stilistinị bruožą. Jis taip pat nurodo ir pagrindinius šių tendencijų skirtumus. Vèlyvojo modernizmo architektūra adaptuoja modernistines idejas ir formas, jas hiperbolizuoja iki kraštutinumų, siekdama sukelti estetinị pasigèrejimą. Postmodernistinè architektūra yra pusiau modernistinè, pusiau tradicinè. Architektūrinès formos iracionalumą bei siekị hiperbolizuoti abstrakčias, racionalias modernistines formas iliustruoja architekto Piet Blom sukurtas laisvalaikio centras Helmonde, Olandijoje (7 pav.). Daugiabriauniai tūriai, įstrižai lyg „užmauti“ ant kolonų, tarsi suskaldo fasadą ị daugybę trikampių ir stačiakampių plokštumų. Postmodernizmui būdingą eklektiką atspindi architekto Ch. Moore projektuota aikštè Piazza d'Italia, Naujajame Orleane, JAV - tai vienas iš būdingiausių postmodernizmo architektūros kūrinių ( 8 pav). Ch. Jencks teigimu, tai yra radikalios
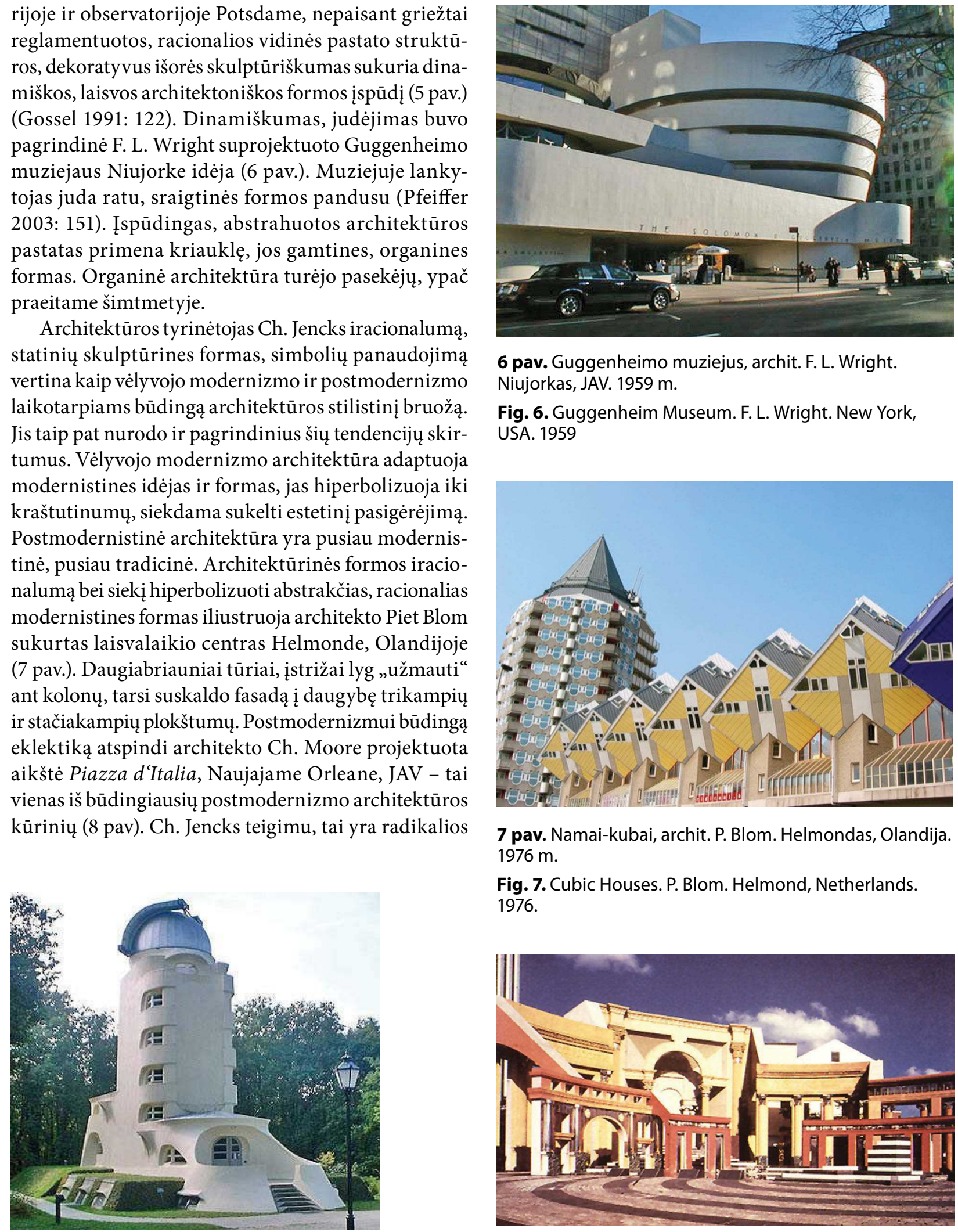

6 pav. Guggenheimo muziejus, archit. F. L. Wright. Niujorkas, JAV. 1959 m.

Fig. 6. Guggenheim Museum. F. L. Wright. New York, USA. 1959

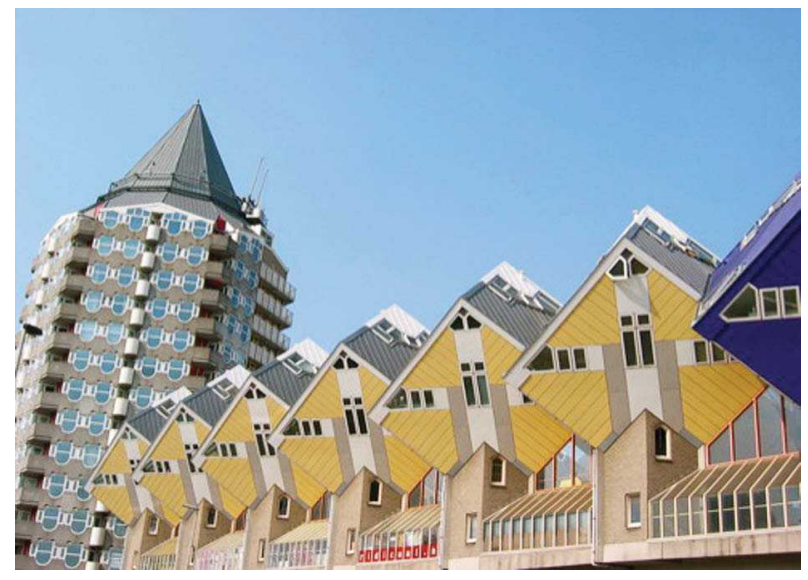

7 pav. Namai-kubai, archit. P. Blom. Helmondas, Olandija. $1976 \mathrm{~m}$.

Fig. 7. Cubic Houses. P. Blom. Helmond, Netherlands. 1976.

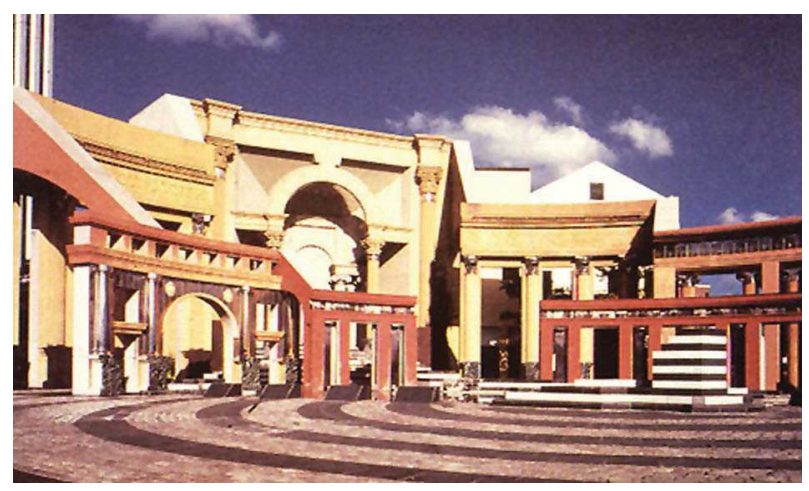

5 pav. Astrofizikos laboratorija ir observatorija, archit. E. Mendelsohn. Potsdamas, Vokietija. 1921-1924 m.

Fig. 5. Observatory and Laboratory of Astrophysics. E. Mendelsohn. Potsdam, Germany. 1621-1624

8 pav. Piazza d'Italia, archit. Ch. Moore. Naujasis Orleanas, JAV. 1979 m.

Fig. 8. Piazza d'Italia. Ch. Moore. New Orleans, USA. 1979. 
eklektikos pavyzdys, nes remiasi trimis tam būtinais bruožais: kontekstualumu, atliekamų funkcijų ịvairove ir pataikavimu vartotojo skoniui (Jencks 1982). Prie žymesnių postmodernistinio laikotarpio architektų priskiriama grupe „SITE“ („BEST“ kompanijos pastatai aštuntajame ir devintajame dešimtmečiuose JAV), F. Hundertwasser (gyvenamasis namas Vienoje, Austrijoje 1986 m.; vyninè Napos slènyje, JAV 1998 m.), H. Hollein (modernaus meno muziejus Frankfurte prie Maino, Vokietijoje, $1991 \mathrm{~m}$.) ir kt.

Postmodernizmo laikotarpiu tarp eklektiškų, dekoratyvių, kičinių formų atsirado nauja architektūros kryptis - dekonstruktyvizmas. Klasikinis menas teige rimtị, nekonfliktiškumą, nerūpestingumą, tačiau dekonstruktyvizmas kaip ir šiuolaikinis menas siekia nustebinti žiūrovą, jis remiasi iracionalumu, netikètumu (Palaima 2006: 146). Frank Gehry projektuodamas savo nuosavo individualaus namo priestatą tarsi tyčiojasi iš M. van der Rohe būdingų tvarkingų plokštumų, deformuodamas formas (langus, grotas), pakreipdamas jas kampu (9 pav.) (Jencks 1982: 217). Salamono Guggenheimo muziejaus projekte (Bilbao) F. Gehry dekonstruktyvizmas igauna amorfinių, organinių formų (10 pav.). Iš pirmo žvilgsnio pastatas atrodo tarsi sunkus, grandiozinis augalas, iracionalios, bioninių formų struktūros tarsi ropščiasi ant tvarkingų, stačiakampių formų. Pastato konstrukcija - neitikètinai sudetinga, projektuojant jau naudotos kompiuterinès technologijos (Jencks 1995: 182, 185). Šiuolaikinèje architektūroje dekonstruktyvizmui taip pat priskiriami tokie architektai kaip Coop Himmelb(l)au (BMW komercinis pastatas Miunchene, Vokietijoje, $2007 \mathrm{~m}$. (11 pav.); teatras Dresdene, Vokietijoje, 1998 m.), Morphosis (Federalinis pastatas San Franciske, JAV,

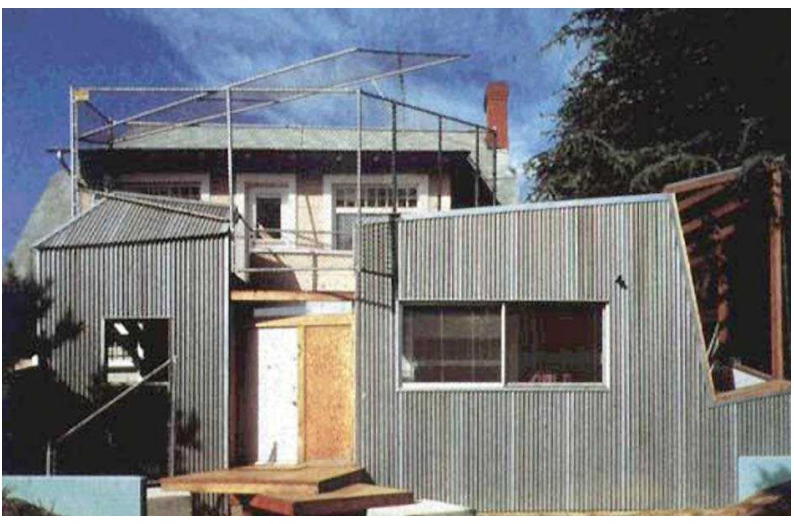

9 pav. Gyvenamasis namas, archit. F. Gehry. Santa Monika, JAV. $1978 \mathrm{~m}$.

Fig. 9. Dwelling house. F. Gehry. Santa Monica, USA. 1978.
$2007 \mathrm{~m}$. (12 pav.); astronomijos ir astrofizikos institutas Pasadenoje, JAV 2008 m.), Z. Hadid (Rozentalio šiuolaikinio meno centras Cincinatyje JAV, 2003 m.; gyvenamųjų namų kompleksas Vienoje, Austrijoje, 2006 m.) ir kt.

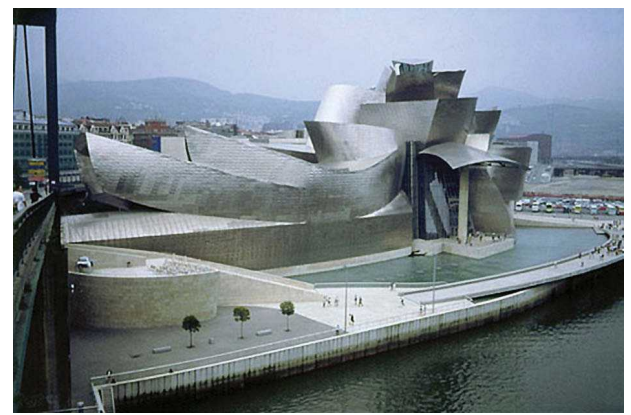

10 pav. Guggenheimo muziejus, archit. F. Gehry. Bilbao, Ispanija. $1997 \mathrm{~m}$.

Fig. 10. Guggenheim Museum. F. Gehry. Bilbao, Spain. 1997

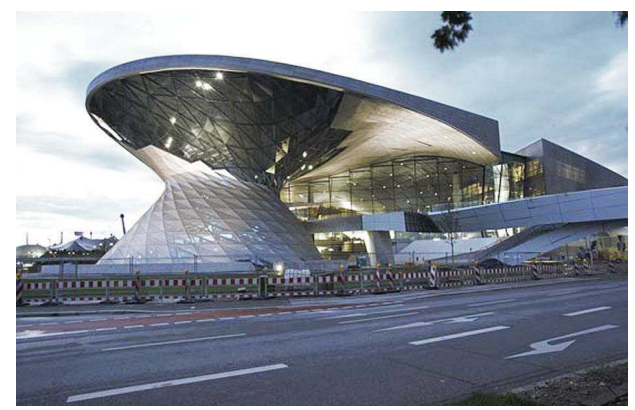

11 pav. BMW pastatas, Coop Himmelb(l)au. Miunchenas, Vokietija. $2007 \mathrm{~m}$.

Fig. 11. BMW building. Coop Himmelb(I)au. Munich, Germany. 2007

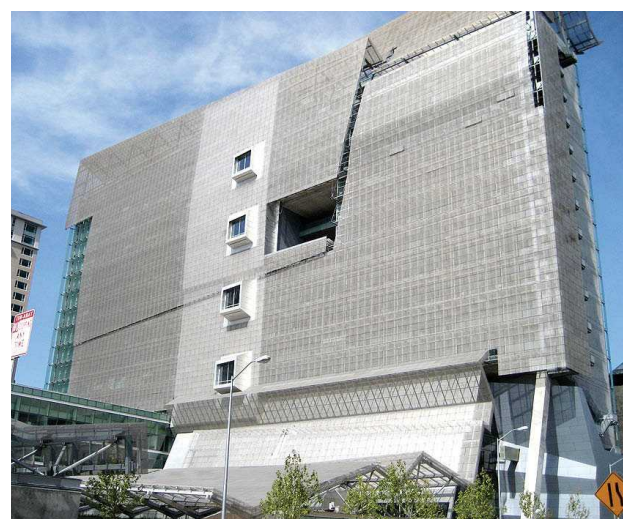

12 pav. Federalinis pastatas, Morphosis. San Franciskas, JAV. 2007 m.

Fig. 12. Federal buiding. Morphosis. San Francisco, USA. 2007 


\section{Iracionalumo tendencijos $\mathrm{XX}$ amžiaus Lietuvos architektūroje}

Lietuvos architektūroje iki pat Pirmojo pasaulinio karo ir XX-ojo amžiaus pradžioje vis dar vyravo eklektizmas - įvairių stilių junginys. Šio laikotarpio pastatuose dominavo orderinès sistemos, renesanso, baroko ir klasicizmo formų imitacijos. Žymesniems šio laikotarpio pastatams priskiriamas Lietuvos nacionalinès filharmonijos pastatas (arch. K. Korojedovas, 1889-1902 m.), dabartinis Rusų dramos teatras (arch. V. Michnevičius, 1912 m.), Petro Vileišio rūmų ansamblis Vilniuje (Mačiulis, Trilupaitytė 2002: 266). Šio laikotarpio projektavimo principai, kaip jau minèta, vis dar rèmèsi orderine sistema, istoristinèmis formomis ir elementais, todèl iracionalumo čia nebuvo. Ekspresyvesnès architektūros apraiškos pastebimos „naujojo stiliaus" pastatuose.

Lietuvoje kaip ir Rusijos imperijoje „naujasis stilius“ buvo vadinamas modernu. Tiesa, šis stilius, palyginus su Vakarų Europos šalimis, Lietuvoje vèlavo maždaug dešimtmečiu. Ankstyvajame šio stiliaus etape iracionalumas pasireiške dekoratyvumu. Šalia racionalios erdvinès struktūros, plačiai naudojamas augalinis dekoravimo motyvas (Buivydas 1999: 72), lanksti, dinamiška ornamentika, ažūrinès metalinès grotelès interjeruose - gausiai kokliais dekoruotos krosnys, lipdiniai, vitražai (Mačiulis, Trilupaitytė 2002: 266-267). Žymesniems šio laikotarpio kūriniams priskiriamas architekto A. Filipovičiaus-Duboviko suprojektuotas gyvenamasis namas M. Valančiaus gatveje (1903 m.), Vilniuje (13 pav.), ir M. Prozorovo projektuotas daugiabutis gyvenamasis namas V. Kudirkos gatveje, Vilniuje.

Tarpukariu pasaulineje architektūroje vyraujant art deco tendencijoms, Lietuvoje šios laisvos ir ekspresyvios architektūros srovès pavyzdžių nèra daug (Buivydas 1999: 74). Vienas žymesnių, šiai pakraipai priskiriamų pastatų - Vytauto Didžiojo muziejus Kaune (arch. V. Dubeneckis, K. Reisonas, K. Krikščiukaitis, 1938 m.) (14 pav.). Pagrindinio korpuso planas - beveik kvadrato formos, turintis aiškią simetrijos aši. Fasadai - taisyklingų proporcijų, dominuoja masyvios plokštumos, perkirstos horizontaliomis langu juostomis (Kančienè 1998). Simetriško plano kompoziciją paivaiirina asimetriškai ịkomponuotas varpų bokštas. Architektūrinè išraiška monumentali, tačiau art deco stiliui artimi motyvai papildo pastato kompoziciją. Nagrinejant iracionalumo tendencijas tarpukario Lietuvos architektūroje, tikslinga panagrinèti ir kiek kitokio pobūdžio - tarptautinių parodu paviljonų ir konkursų - objektus. 1939 m. Lietuva pirmą kartą dalyvavo tarptautineje parodoje, vykusioje

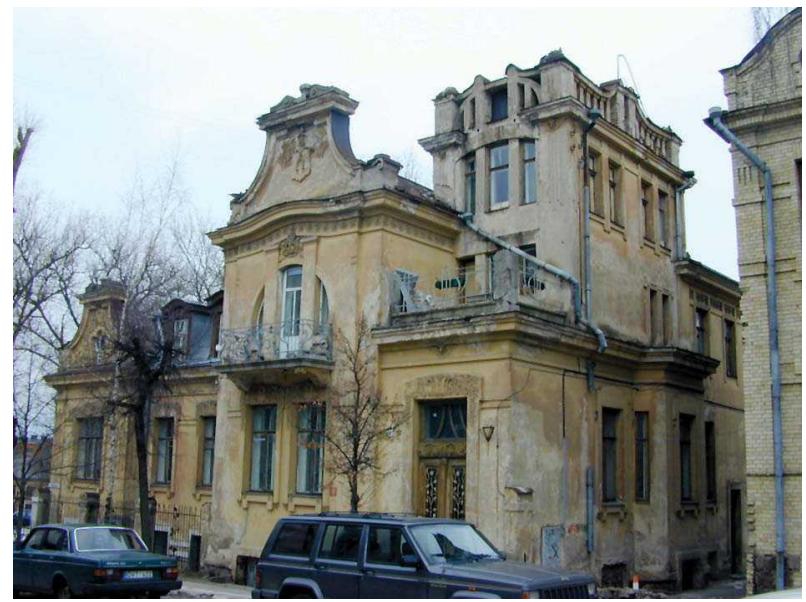

13 pav. Gyvenamasis namas, Valančiaus g., archit. A. F. Dubovikas. Vilnius. 1903 m.

Fig. 13. Dwelling house in Valančius str. A. F. Dubovikas. Vilnius. 1903

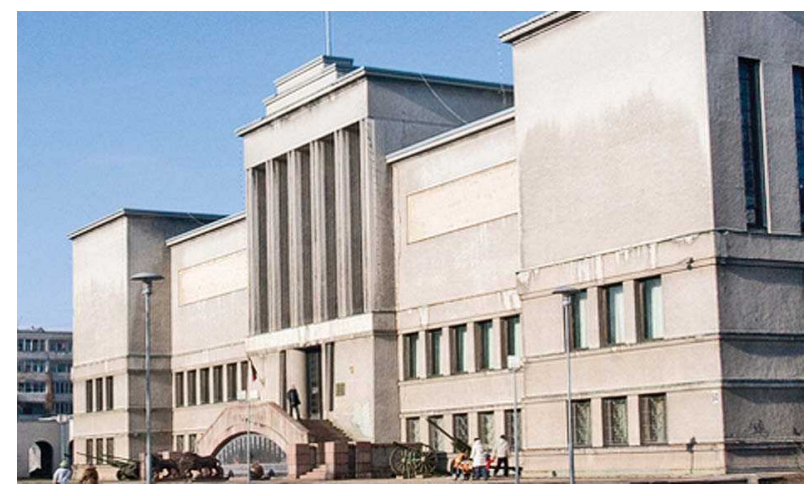

14 pav. Vytauto Didžiojo muziejus, archit. V. Dubeneckis, K. Reisonas, K. Krikščiukaitis. Kaunas. 1938 m.

Fig. 14. Vytautas Magnus Museum. V. Dubeneckis, K. Reisonas, K. Krikščiukaitis. Kaunas. 1938

Niujorke, JAV. Architekto A. Šalkauskio suprojektuotas Lietuvos paviljonas, suderinęs racionalų ir iracionalų pradus, atspindèjo naujas lietuvių architektūros tendencijas (Buivydas 2006a: 16, 17). Po 1928 m. j̧vykusio konkurso, projektuoti Prisikèlimo bažnyčią Kaune buvo pavesta Karoliui Reisonui. 1930 m. patvirtintas pirmasis projekto variantas. Gotiško silueto veržlus bokštas, apvytas kolonomis, turëjo aliuzijų i Čiurlionio ar Šimonio paveikslus (Kančienè 1996: 55). Dèl visuomenès nepasitenkinimo ir per didelès sąmatos buvo paprašyta parengti kitą bažnyčios projektą.

Jau pokariu, sovietiniais metais statytas nacionalinis dramos teatras Vilniuje (archit. A. Nasvytis, V. Nasvytis, projektas sukurtas 1966-1969 m., igyvendintas $1981 \mathrm{~m}$.), ypač jo pagrindinis fasadas, taip pat gali būti iracionalios architektūros pavyzdys. 
Pagrindinis įejimas iš prospekto - tik siaura, žema stiklo pertvara, jungianti senus namus, tačiau virš jos kylanti S. Kuzmos skulptūra „Mūzų šventë“ yra tikrasis teatro fasadas (Mačiulis 2007: 242). Panašių skulptūrinių sprendimų, kai derinama racionali konstrukcinè struktūra ir dekoratyviniai elementai, galima rasti ir daugiau, pavyzdžiui J. Šeiboko projektuotame Ryšių ministerijos administraciniame komplekse Vilniaus gatveje, Vilniuje (1967 m.), A. ir R. Šilinskų Fizioterapijos gydykloje Druskininkuose (1981 m.).

Simbolizmas, būdingas vèlyvojo modernizmo architektūrai (Jencks 1982: 16), pastebimas ir Lietuvos architektų darbuose. Gamtiniai motyvai poetiškai interpretuojami Arno Dineikos projektuotame profilaktoriume Bijoteje, Šiaulių raj. (1985 m.). Statinio prototipas, trykštančio vandens purslai, pasirinkti atsižvelgiant ị suniokotą reljefą, buvusị karjerą. Tokiam gamtinių, bioformų pastatų tipui galima priskirti ir poilsio namus „Sūrutis“ Druskininkuose (1982 m.) (Nekrošius 2008: 69). Savotišką bangų motyvą kaip pagrindinę pastato koncepciją panaudojo ir A. Čepys, projektuodamas skaityklą-kavinę Palangoje, Vytauto g. (Buivydas 1999: 74).

Aštuntojo dešimtmečio viduryje, G. Baravykui suprojektavus Santuokų rūmus Vilniuje (1974 m.), Lietuvos moderniojoje architektūroje buvo pradètas naujas etapas - išryškejo iracionalumo bei ekspresyvumo tendencijos. Pastatų kompozicijoje vyrauja skulptūrinès, dekoratyvinès formos (Mačiulis 2002: 339), asimetriška, dinamiška plano kompozicija (Gerliakas 1996: 60). Skulptūriškomis formomis pasižymi ir J. Šeiboko Lietkoopsąjungos administracinis pastatas Gedimino pr. Vilniuje (1979 m.) (15 pav.). Tūrio daugialypiškumas išsiskiria iš aplinkinio užstatymo,

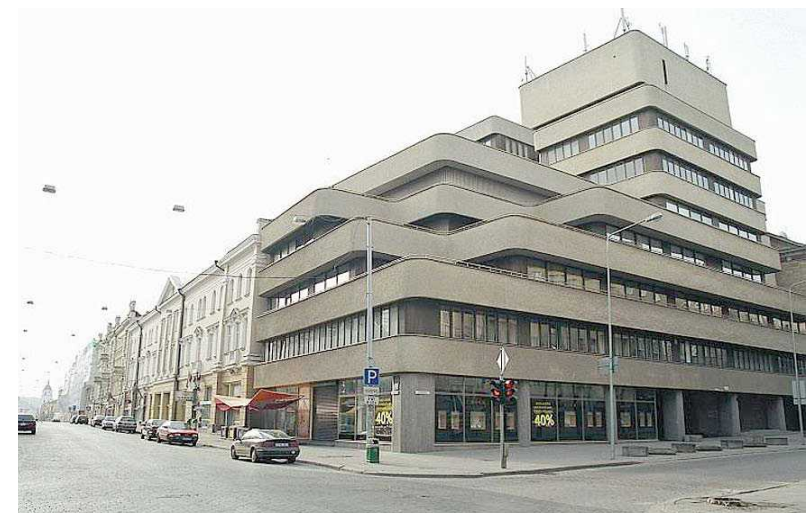

15 pav. Lietkoopsąungos administracinis pastatas, archit. J. Šeibokas. Vilnius. 1979 m.

Fig. 15. Administrative building. J. Šeibokas. Vilnius. 1979 visą statinio perimetrą apima tik antrasis aukštas, visi kiti aukštai skirtingi - mažejjančių tūrių. Architekto J. Anuškevičiaus suprojektuota Rokiškio sūrių gamyklos poilsinè „Žiogas“ taip pat turi vèlyvojo modernizmo raiškos bruožų. Dar vienas ekspresyvios architektūrinès kompozicijos pavyzdys galètų būti kavinès „Nendre“" pastatas Trakuose, projektuotas V. Dičiaus ir L. Ziberko (1976-1984 m.). Dinamiška geometrinių tūrių kompozicija ị viršų platėjančiais karnizais primena karaimų tradicinès architektūros ir aprangos formas. Tai suteikia statiniui kontekstualumo (Nekrošius 2008).

Manieristiškos, postmodernizmui būdingos išraiškos daugiasluoksniškumui artimais pavyzdžiais galima laikyti polifunkcinị Centrum kompleksą Vilniuje (archit. K. Pempe, G. Ramunis, K. Kisielius, A. Asauskas, 1996 m.) (16 pav.); prekybos centrą „Promenadas" Vilniuje (archit. S. Gecas, R. Pilkauskas, 1995 m.); pramogų centrą „Šachmatine““ Palangoje (archit. G. Likša, I. Likšienè, 1996 m.); buitinių paslaugų centrą Klaipèdoje (archit. G. Čiučiurka, V. Janulis, S. Plungè, $1997 \mathrm{~m}$.).

Taigi, Lietuvoje kaip ir Vakaruose iracionaliosios architektūros bruožai, pradžioje išryškeję moderno architektūroje, gyvavo tarpukariu, vèlyvojo modernizmo laikotarpiu, taip pat ir postmodernizmo laikotarpiu. Šiuolaikinè iracionalioji architektūra užsienio tyrinėtojų siejama su dekonstruktyvizmu, ịvairių naujų krypčių, siejamų su kompiuterinèmis technologijomis, atsiradimu, todèl ši tendencija turi prielaidų plètotis (17 pav.). K. Lupeikis monografijoje „Minimalizmo galia" pristate formos transformavimo metodiką, kuri gali būti taikoma aukštųjų mokyklų studijų programose, taip pat ir architektūros praktikoje $(18,19$ pav.) (Lupeikis 2007).

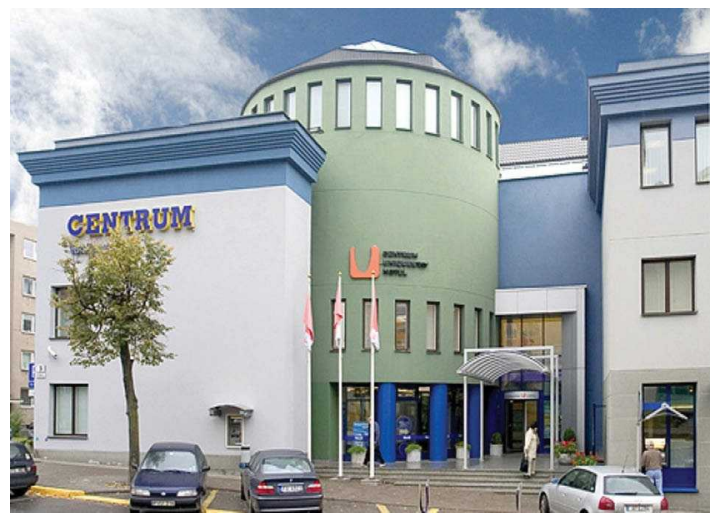

16 pav. Centrum viešbutis, archit. K. Pempè, G. Ramunis, K. Kisielius, A. Asauskas. Vilnius. 1996 m.

Fig. 16. "Centrum" hotel. K. Pempè, G. Ramunis, K. Kisielius, A. Asauskas. Vilnius. 1996 


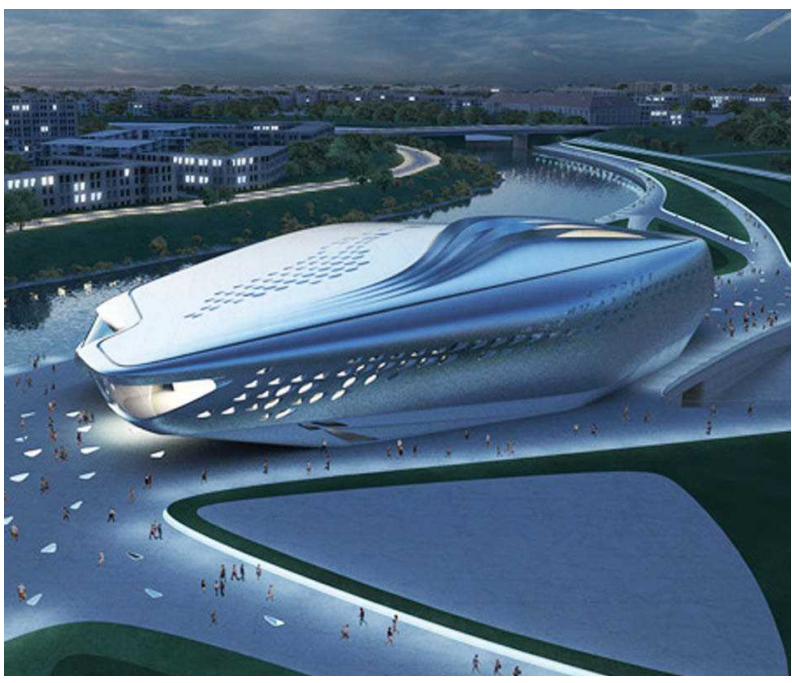

17 pav. Guggenheimo-Ermitažo muziejus, archit. Z. Hadid. Konkursinis projektas. Vilnius. 2008 m.

Fig. 17. Guggenheim-Ermitage Museum. Z. Hadid. Competition project. Vilnius. 2008

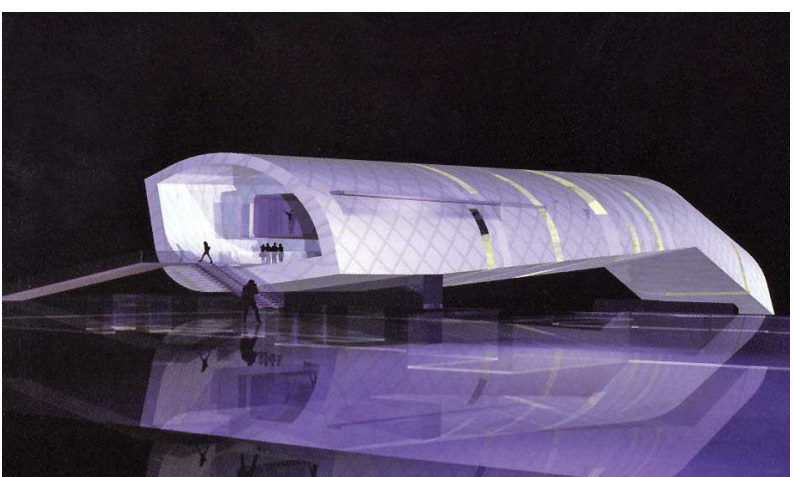

18 pav. Tiltas-muziejus, archit. K. Lupeikis. Venecija. $2006 \mathrm{~m}$.

Fig 18. Bridge-museum. K. Lupeikis. Venice. 2006

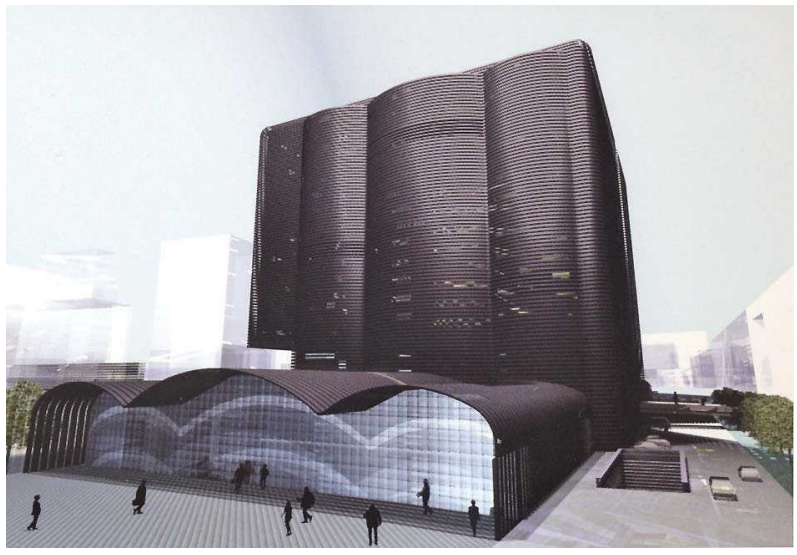

19 pav. Teisingumo rūmai, archit. K. Lupeikis, S. Saulènas. Paryžius. $2006 \mathrm{~m}$.

Fig. 19. Paris court. K. Lupeikis, S. Saulènas. Paris. 2006

\section{Išvados}

1. Iracionalumas pasireiškia kaip priešprieša racionalumui, pragmatiškumui, pozityvizmui, technicistinei morfologijai. Jis grindžiamas dekonstravimo, neapibrěžtumo, grubumo, dramatiško ekspresyvumo, intuityvumo, atsitiktinumo nuostatomis. Formai dažnai būdinga atektoniškumas, disharmonija.

2. Iracionalumas architektūroje pasireiškia keliais būdais: dekoratyvumu, ornamentika, polichromija ir formos bei konstrukcijos deformacija, daugiasluoksniškumo ir skulptūriškumo principais.

3. Iracionalumo apraiškas architektūroje veikè keletas faktorių: tokios filosofinès kryptys kaip reliatyvizmas, iracionalizmas, intuityvizmas, psichoanalizé, dekonstruktyvizmas; ir meno tendencijos: kubizmas, simbolizmas, ekspresionizmas, art deco, siurealizmas, konceptualizmas, popartas ir kt.

4. XX a. užsienio ir Lietuvos architektūroje iracionalumo apraiškos pastebimos moderno, art deco, organinès, vèlyvojo modernizmo, postmodernizmo, dekonstruktyvizmo architektūros tendencijų pastatuose.

\section{Literatūra}

Buivydas, R. 2006a. Lietuviškieji XX a. reprezentacinès architektūros variantai, iš Architektūra: pozityvai ir negatyvai. Vilnius: „Ex Arte“, 12-24.

Buivydas, R. 2006b. Naujieji meninio vaizdo ženklinimai XX a. architektūroje, iš Architektūros kompozicijos tyrimai: Mokslinių straipsnių rinkinys. Vilnius: Technika, 45-49.

Buivydas, R. 1999. XX a. architektūra: iracionalizmas, Archiforma 2: 71-77.

Gerliakas, K. 1996. Gediminas Baravykas: asmenybė ir kalba, Archiforma 1: 60-64.

Gossel, P.; Leuthauser, G. 1991. Architecture in the twentieth century. Koln: Taschen.

Jencks, Ch. 1982. Architecture today. London: Academy Editions.

Jencks, Ch. 1995. Architecture of the Jumping Universe. London: Academy Editions.

Kančienè, J. 1996. Lietuvos architektų orientyrai tarpukaryje, Archiforma 1: 55-59.

Kančienè, J. 1998. Lietuvos moderno pastatai. Vilnius: Savastis.

Kučinskas, R. 2009. Globalios architektūros pavidalai Vilniaus kontekste, Mokslas - Lietuvos ateitis 1(2): 49-52 Vilnius: Technika.

Le Corbusier. 1986. Towards a New Architecture. New York: Dover.

Lupeikis, K. 2007. Minimalizmo galia. Vilnius: Technika. doi:10.3846/1372-M 
Mackay, D. 1985. Modern architecture in Barcelona (1854-1939). University of Sheffield.

Mačiulis, A. 2007. Architektai Algimantas ir Vytautas Nasvyčiai. Vilnius: VDA.

Mačiulis, A. 1997. Architektūra. Stiliai, kompozicija, menu squeika. Vilnius: VDA.

Mačiulis, A. 2002. Modernioji lietuvių architektūra, iš Lietuvos dailes istorija. Vilnius: VDA, 278-280.

Mačiulis, A.; Trilupaitytè, S. 2002. Amžiaus pradžios architektūra: istorizmas ir modernas, iš Lietuvos dailes istorija. Vilnius: VDA, 266-268.

Melvin, J. 2007. ...izmai. Vilnius: Mūsų knyga.

Nekrošius, L. 2008. Struktūralizmo idèjos šiuolaikinèje Lietuvos architektūroje: daktaro disertacija. Vilnius: Technika.

Palaima, J. 2006. Harmonija architektūroje: proporcijos ir mastelis. Vilnius: VDA.

Pfeiffer, B. B. 2003. Frank Lloyd Wright. Koln: Taschen.

Schumacher, P. 2008. Parametricism as Style - Parametricist Manifesto [interaktyvus]. Venecija [žiūrèta $2010 \mathrm{~m}$. gegužès 12 d.]. Prieiga per internetą: <http://www.patrikschumacher.com/Texts/Parametricism\%20as\%20Style.htm>.

Stirling, J. 1997. Ronchamp: Le Corbusier's Chapel and the Crisis of Rationalism, in Theories and Manifestoes of contemporary architecture. London: Academy editions, 16-18.

Wolfflin, H. 2000. Pamatines meno istorijos savokos. Vilnius: Pradai.

\section{IRRATIONALITY IN GLOBAL AND LITHUANIAN ARCHITECTURE OF THE 20TH CENTURY}

\section{A. M. Mačiulis}

Abstract. The paper analyses irrationality as an expression of modern architecture, overviews the concept of irrational architecture. Various art and philosophical trends, that influenced the development of architecture in the 20th century, are analysed. Influences of global and Lithuanian analogues of irrational architecture on the development of architectural styles are presented. Since the concept of irrational architecture hasn't been widely analysed, the paper suggests several approaches of analysis of irrational forms in architecture. The author arrives at the following conclusions:

- Irrationality is an opposite expression of rationality, pragmatism, posityvism, technicist morphology. It's based on deconstruction, indetermination, roughness, dramatic expression, etc.

- The effect of irrationality can be obtained by two ways: using decorations, ornaments, polichromy, and using deformations of forms and constructions.

- Irrational trends in architecture are caused by several factors. Philosophical trends such as reliatyvism, irrationalism, intuityvism, psychoanalysis, deconstructyvism, and art trends such as cubism, symbolism, expressionism, art deco, surrealism, etc.
- Irrational trends in global and Lithuanian architecture of the 20th century can be noticed in art nouveau, art deco, organic, late modern, postmodern, deconstructyvist architectural styles.

Keywords: rationality, irrationality, decorative, plastic, sculptural form, multilayer.

\section{ALGIMANTAS M. MAČIULIS}

Master, doctoral student, Dept of Architecture, Vilnius Gediminas Technical University (VGTU), Pylimo g. 26/Traku g. 1, 01332 Vilnius, Lithuania.

E-mail: algimantasmaciulis@yahoo.com

Doctoral student, VGTU, 2009. Master of Architecture, Vilnius Academy of Fine Arts, 2007-09. Bachelor of Architecture, Vilnius Academy of Fine Arts, 2003-07. Research interests: influences in contemporary Lithuanian architecture. 